inOfedia $\quad \begin{aligned} & \text { InMedia } \\ & \text { The French Journal of Media Studies }\end{aligned}$

8.2. $\mid 2020$

What do Pictures Do? (In)visibilizing the Subaltern

\title{
"Down-Under" the Veil of Invisibilization: The Narrative of Aboriginal Subjectivity in Michael Cook's Photomontages.
}

Laura Singeot

\section{(2) OpenEdition}

Journals

Electronic version

URL: https://journals.openedition.org/inmedia/2430

DOI: 10.4000/inmedia.2430

ISSN: 2259-4728

Publisher

Center for Research on the English-Speaking World (CREW)

\section{Electronic reference}

Laura Singeot, "'Down-Under" the Veil of Invisibilization: The Narrative of Aboriginal Subjectivity in Michael Cook's Photomontages.", InMedia [Online], 8.2. | 2020, Online since 22 October 2021,

connection on 09 November 2021. URL: http://journals.openedition.org/inmedia/2430 ; DOI: https:// doi.org/10.4000/inmedia.2430

This text was automatically generated on 9 November 2021.

(c) InMedia 


\title{
"Down-Under" the Veil of Invisibilization: The Narrative of Aboriginal Subjectivity in Michael Cook's Photomontages.
}

\author{
Laura Singeot
}

\section{Introduction}

1 As terra nullius, Australian territory was considered an empty land, which legitimized its annexation and colonization by the Crown: this lack of recognition, based on the colonizers' blindness to Aboriginal peoples in a way, eventually resulted to their erasure from the land, which facilitated, at least legally, the process of colonization, since for example no treaty was signed. This original historical invisibilization led to dire consequences on Aboriginal communities, and to assimilation-in other words, cultural and physical invisibilization. This annihilation did not only erase native bodies from the landscape, but it also led to the obliteration of their culture. Cultural genocide was underway from the outset of colonization.

2 Part of this meant that colonizers did not think that native populations could have artists amongst them, who could produce "fine arts" or "high arts". The artefacts that were brought back to Europe were considered "primitive". Those objects were then exhibited in ethnographic museums and given scientific importance, while any aesthetic qualities were usually reserved for Western art. The idea of terra nullius was consequently transferred on an artistic level, in addition to a geographic and demographic one. Aboriginal traditional "art"-and more specifically paintings-was first created to satisfy European art lovers who brought it back to Europe and exhibited it in galleries in the $20^{\text {th }}$ century. ${ }^{1}$ This art would only be recognized as "Aboriginal" if it was deemed "traditional" and "authentic", that is to say painted by a member of an Aboriginal community and often representing an Aboriginal Dreaming story using the 
distinctive dot-style for example, ${ }^{2}$ while contemporary art is conventionally labelled as Occidental. ${ }^{3}$

3 Photography was one of the privileged white artistic media par excellence. As such, Aboriginal photographers have had to struggle to be recognized. Indeed, Catherine De Lorenzo traces Aboriginal photographic practices in her article "Agency and Authorship in Australian Photo Histories," in which she argues that:

much recent Australian art history and curatorial practice has been undergoing an 'Aboriginal turn,' incorporating and normalizing Aboriginal art into [...] contemporary Australian art and art history. Within Australian photo histories such work has been more complex. ${ }^{4}$

Lorenzo's Australian photo-historiography emphasizes that turn which, although slow, has made a significant and long-lasting impact on the field. Using photography as an artistic medium is also tinged with a political dimension, as Craig and Presley explain:

The democratisation of photography led to its enthusiastic uptake across the world. For Indigenous artists, it holds the power to reclaim their own image. In doing so, they overturn the history of the camera as an ethnographer's tool, whereby Indigenous people were objectified, classified-treated as flora and fauna-and recorded in response to a misguided Western expectation that they would eventually 'die out'.

5 However, more specific studies of photography in Australia have shown that ever since its development in the $19^{\text {th }}$ century, it relied on Indigenous agency. It was often understood by Western scholars that Aboriginal populations were misrepresented since the controlling eye behind the photographic lens was more often than not a Westerner's. In fact, in Calling the Shots: Aboriginal Photographies, Jane Lydon states that Aboriginal agency has always been a determining principle. From the first ethnographic use of photography to its more recent changes including the democratization and spread of technical tools in Aboriginal communities, Aboriginal Australians have always shown interest in handling this specific means of representation. In a very detailed analysis, Lydon demonstrates that Indigenous agency was always present and eventually took a political turn when Aboriginal activists used this media to back up their political claims and document their struggle in the twentieth century. She not only studies the participation of Indigenous Australians in the production of photographs themselves, but she also explores how they managed to spread and communicate their views and create knowledge via the image. She briefly evokes photography as art in the artistic turn of the 1980s when indigenous photographers such as Tracey Moffatt, Michael Riley or Brenda L. Croft used that medium for cultural and political claims, "representing Aboriginal culture [...] from an explicitly Aboriginal perspective". ${ }^{6}$ In the 1990s, Aboriginal photography as art became internationally recognized thanks to those same artists who often found inspiration in photographic archives, whereas more recently, others, such as Christian Thompson and Michael Cook, have also managed to become the international ambassadors of this art form, each with their own specificity and signature, imagining very diverse representations of their cultural heritage and identity. As a consequence, it seems that Indigenous photography-by, of, and for Indigenous people-has been intertwined with political, cultural, and epistemological issues.

6 These considerations echo some Indigenous photographers' concern with offering a new take on history and colonialism in their works. For instance, Michael Cook's photomontages are informed by the former use of photography by ethnographers ${ }^{7}$ and 
highlight the need for new histories to be told and interpretations to emerge. First having successfully worked in the fashion industry, Michael Cook, a photographer of Aboriginal descent, started developing artistic projects of his own in 2008. The transition was smooth as he was already used to working in a demanding environment that required close attention be paid to the aesthetics of the images produced. His work exposes Western narratives of colonialism or of power and hegemony in a contemporary context. Although most of his photographs can be described as portraits, as in the series The Mission (Fig. 1), Broken Dreams (Fig. 2) or Through my Eyes (Fig. 3), they also stage other elements and rely on specific techniques that add much more intensity and intention behind each picture. For example, the multiplication of one single Aboriginal figure in Majority Rule and the recurrent use of layering in his other series offer a stark contrast with Western systems of representation. Throughout the years, Cook's work has gained momentum on the international stage, being exhibited in art galleries but also in museums and universities. As a consequence, it is all the more relevant to focus on his photomontages now as his first 10-year survey exhibit was in August 2020 at the Sunshine Coast University in Queensland.

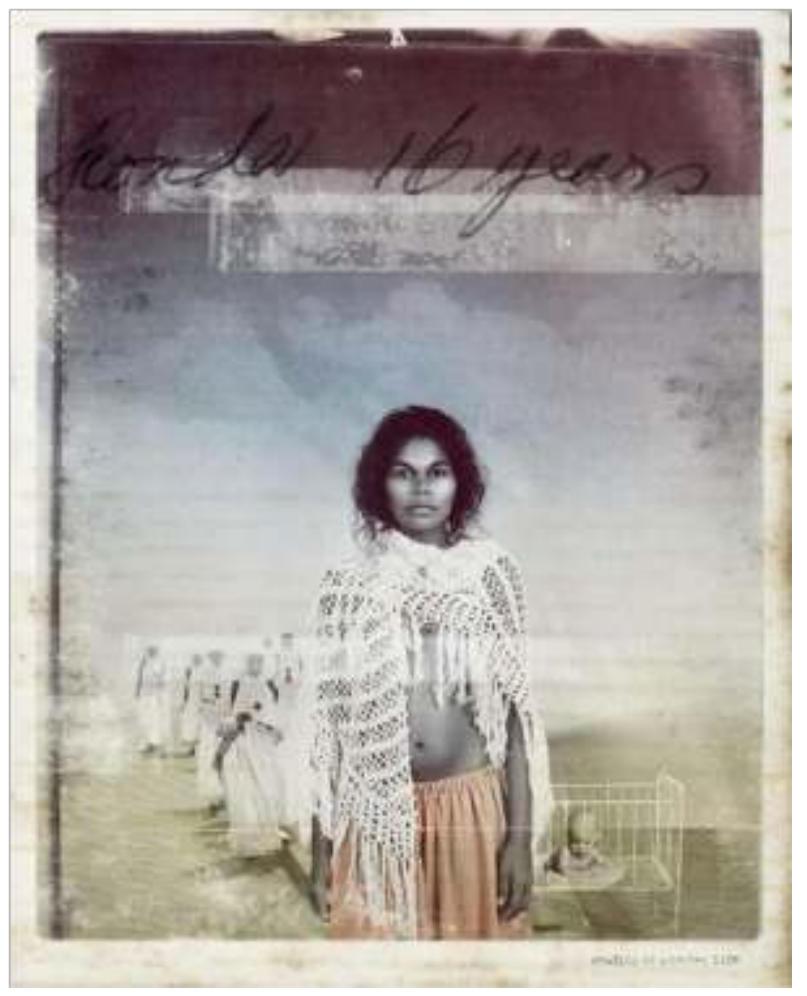

Fig. 1: Cook, Michael, The Mission (Heading to a better life), 2011.

Inkjet print (Epson UltraChrome K3 inks on Hahnemuhle Photo Rag Bright White 310 gsm paper). Size $124 \mathrm{~cm} \times 100 \mathrm{~cm}$. 


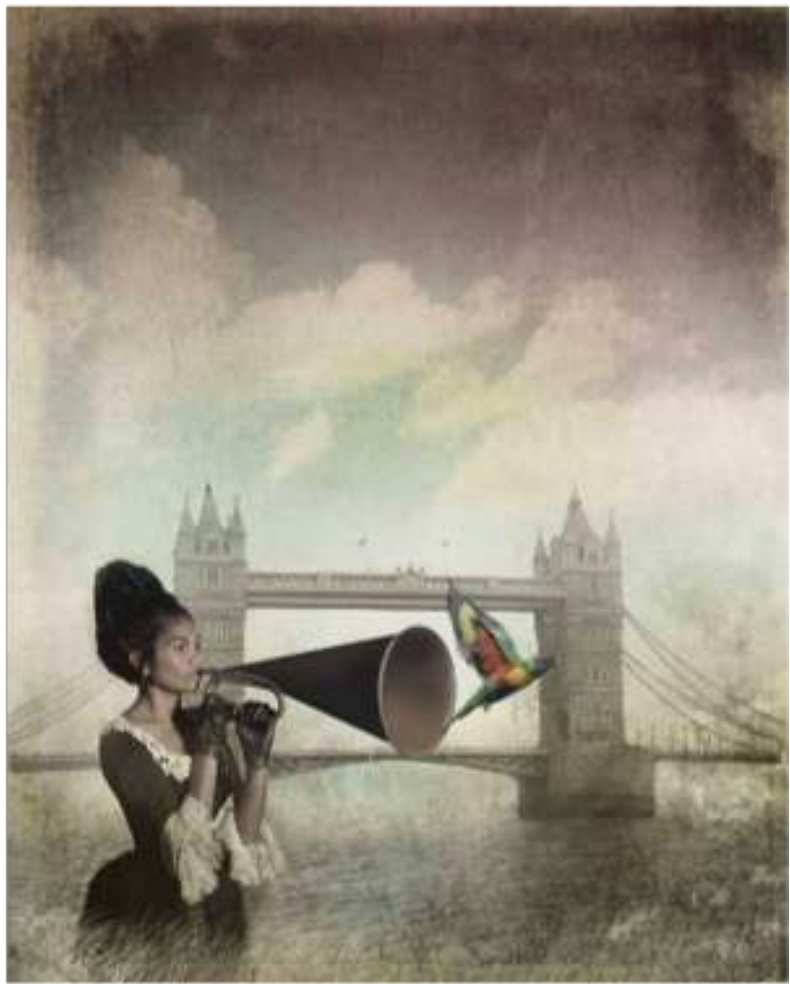

Fig. 2: Cook, Michael, Broken Dreams\#2, 2010.

Inkjet print (Epson UltraChrome K3 inks on Hahnemuhle Photo Rag Bright White 310 gsm paper). Size $124 \times 100 \mathrm{~cm}$.

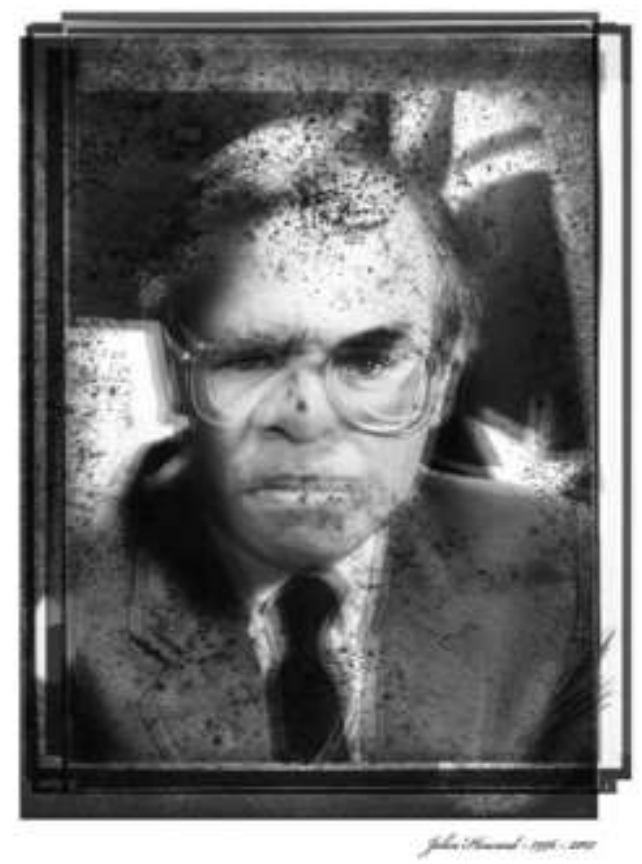


Fig. 3: Cook, Michael, Through my Eyes (John Howard), 2010.

Inkjet print (Epson UltraChrome K3 inks on Hahnemuhle Photo Rag Bright White 310 gsm paper). Size $50 \mathrm{~cm} \times 40 \mathrm{~cm}$.

7 Michael Cook positions his work at the crossroads of epistemological and aesthetic issues, showing that Indigenous art can also be contemporary and innovative. While adding different layers of photographic materials to create original art works that are referred to as "real narratives", he mixes elements from both cultures, Western and Aboriginal, whose dialogue reveals the mechanism of cultural exchanges and questions Western epistemology. As a consequence, focusing on the photomontage and layering techniques, I will demonstrate how Cook exposes and debunks former colonial epistemologies while making two different visions of the world coexist. Far from being synonymous with occlusion and opacity, layering paradoxically becomes the privileged means of unveiling and discovering the recurrent invisibilization processes that systematically targeted Indigenous Australians in history. As a consequence, it is not so much about an expansion than a reconfiguration of the visual field that is targeted by Cook in his art. Finally, I will endeavour to show that by rehistoricizing invisibilization, Cook's photography eventually advocates reconciliation, while repositioning an aestheticized Indigenous subject at the centre of his work.

\section{Photomontage as "Bricolage": A Dialectic Co-Presence}

Michael Cook's artistic signature relies on sharp aesthetics mostly derived from his specific use of the photomontage technique: one of his digital art pieces can sometimes be the result of the superposition of 30 different images or layers. This association of technique, technology and high aesthetization, enables Cook to offer an immersive experience to the viewers who cannot help but recognize and understand the seriousness of the issues he tackles and engages with in his works of art. Here, photomontage seems to go hand in hand with what other theorists have termed "bricolage", enabling the artist to associate disparate cultural elements from different backgrounds, from Aboriginal or European cultures, in the same piece of art. Stephen Muecke sums up the result of the use of "bricolage" as follows, "Bricolage, in any form, sets up a double vision, it forces a juxtaposition of forms and new meanings must emerge." In Cook's works of art, the co-presence of different cultures seems to be mirroring what happens, or should happen in contemporary society. As a matter of fact, "bricolage" leads the photographer to create an artistic palimpsest, formed with different layers which are superimposed and interact especially thanks to a play on transparency. Two complementary perceptions give Cook's images their unique quality: a synchronic accumulation of Indigenous and Western elements, associated to the diachronic dimension of the temporal layers whose interplay also contributes to the uniqueness and reflexivity of Cook's photomontages. Such an artistic palimpsest relies on two specific artistic techniques described by Boaventura de Sousa Santos, the "sfumato" and the "mestizaje":

Mestizaje [...] is a way of pushing sfumato to its utmost or extreme. Sfumato operates through the disintegration of forms and the retrieval of fragments, mestizaje operates through the creation of new constellations of meaning, which are truly unrecognizable or blasphemous in light of their constitutive fragments and in the construction of a new logic. [...] This productive-destructive process tends to reflect the power relations among the original cultural forms (that is, 
among their supporting social groups), and this is why baroque subjectivity favors the mestizajes in which power relations are replaced by shared authority [...]. ${ }^{9}$

This association of fragments and new emergent meanings engenders what Santos calls "transculturation" as a "constant process of transition between cultures."

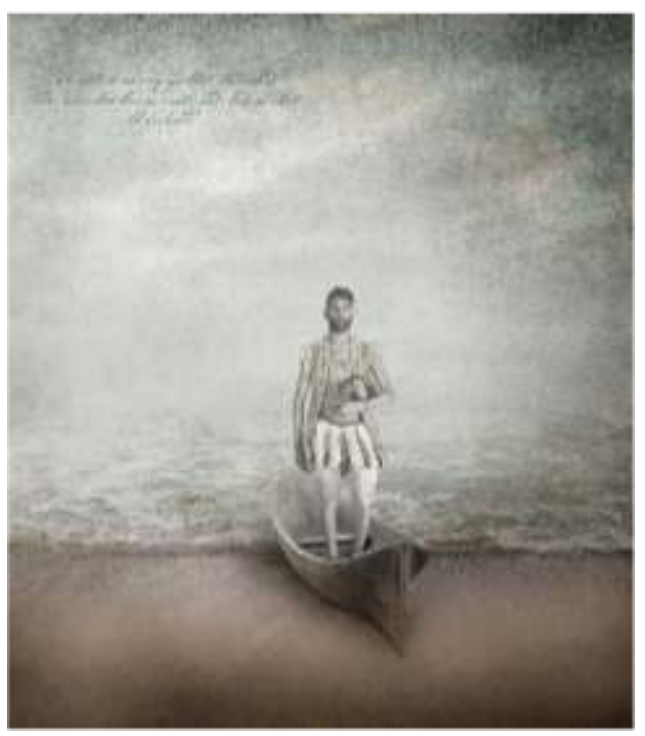

Fig. 4: Cook, Michael, Civilized\#6, 2012.

Inkjet print (Epson UltraChrome K3 inks on Hahnemuhle Photo Rag Bright White 310 gsm paper). Size $100 \times 87.5 \mathrm{~cm}$

In Cook's photomontages, this process is best perceived in the constant juxtaposition of cultural elements from different sources which are shot separately and placed together in the same image, whether it be the models themselves, the props, settings, or fauna and flora. In the series Civilized (2012) (See Fig. 4), excerpts from Captain James Cook's journals ${ }^{11}$ are also placed on top of the photographs, as direct historical references, offering another angle through which one could interpret the photograph. In one interview, the artist reflected on this practice, acknowledging its paramount importance in his work:

I sometimes start with an idea, or sometimes I start with the title like I did with 'Undiscovered'. The latest one was based on Captain Cook's journals. Ideas can come up from anywhere. [...] I normally layer up. [...] My creation is starting with an idea and then building on that idea. I layer and layer until I get the finish product that I want. [...] First thing I shoot is the background so I can see the lighting conditions. Most of the works are layered up to create a finished project that usually has anywhere between 5 - 30 layers. ${ }^{12}$

11 Consequently, each layer of Cook's works should be read and dissected in order to understand and interpret the different intertextual or intervisual references that are made. The artist's inspiration taken from historical meaningful events leads him to add other imaginary elements that are used to transform and complete his artistic vision, but always leaving room for the viewer's interpretation. This operatory mode recalls another artistic influence, that of the Pictorialists (a photographic movement that began at the end of the $19^{\text {th }}$ century and lasted until the beginning of the $20^{\text {th }}$ ), whose works staged unreal, evanescent situations and landscapes, some in kind of dreamlike worlds in which the characters evolved. Lisa Chandler best describes this trend in Cook's art: 
[...] the Pictorialists [...] imaginatively combined and altered negatives in order to create imaginary realities rather than documenting existing ones. [They] employed compositional and other techniques derived from painting traditions, sometimes incorporated a softened focus, and were interested in evoking emotions through their constructed worlds [...]. Similarly, Cook overlays and blends diverse elements -soft foamy seas, ethereal grey skies, starkly delineated figures and sometimes hand-written script-to produce fictional narratives invested with mystery and memory [...].1.

The atmosphere in Cook's works may indeed appear quite unreal and dreamlike and the fact that historical documents are associated with imaginary elements or characters emphasize even more this pictorialist influence relying on "creating imaginary realities", as paradoxical as it may seem. As a matter of fact, Cook's aesthetic is sharp and precise, leading the viewer to think that the photographs might still be representing some kind of reality. Such an artistic "bricolage" exorcises in a way the ideology that legally inscribed the Australian territory as a terra nullius: the work of art is the territory in which two cultures coexist, interact, relate, and eventually create a new whole. As Cook explores and reinvents the territory of digital photography as Indigenous art, his artistic technique perfectly illustrates the expression used by Edward Said in Culture and Imperialism: "bricolage" becomes in fact the result of “overlapping territories, intertwined histories". ${ }^{14}$

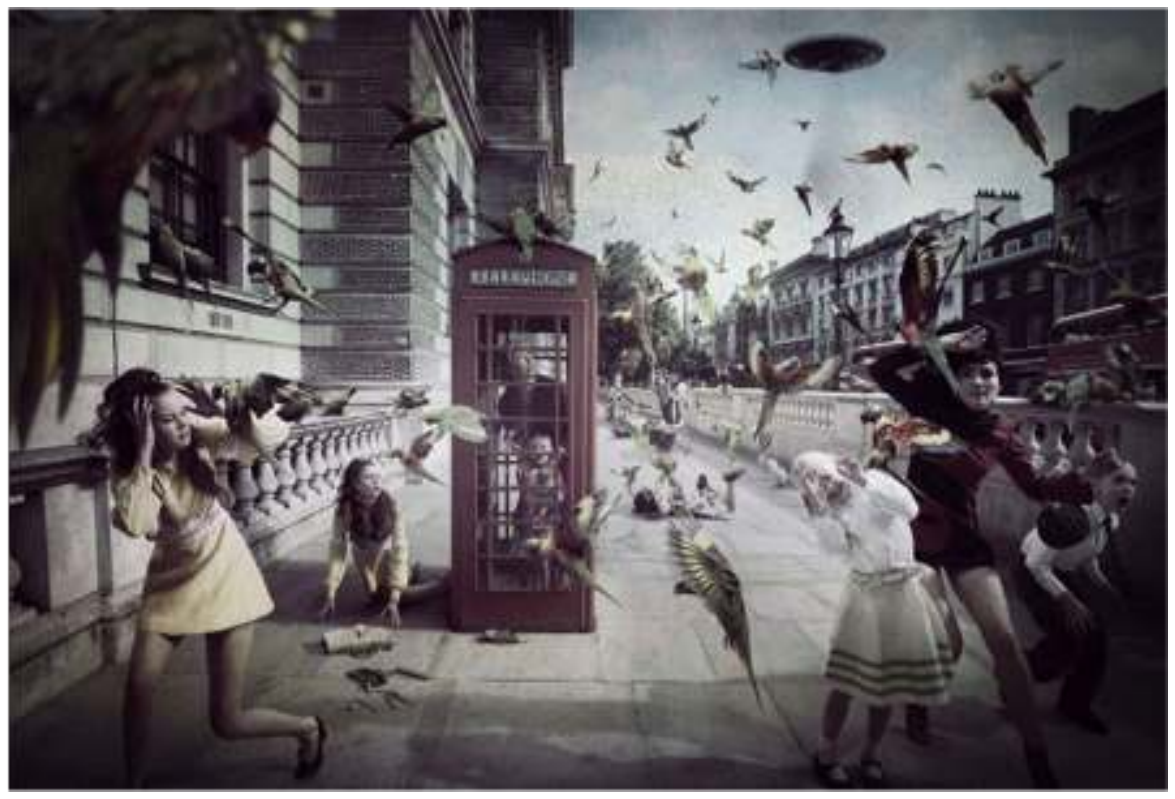

Fig. 5: Cook, Michael, Invasion (Telephone), 2017.

Inkjet print (Epson UltraChrome K3 inks on Hahnamuhle Photo Rag Bright White 310 gsm paper). 


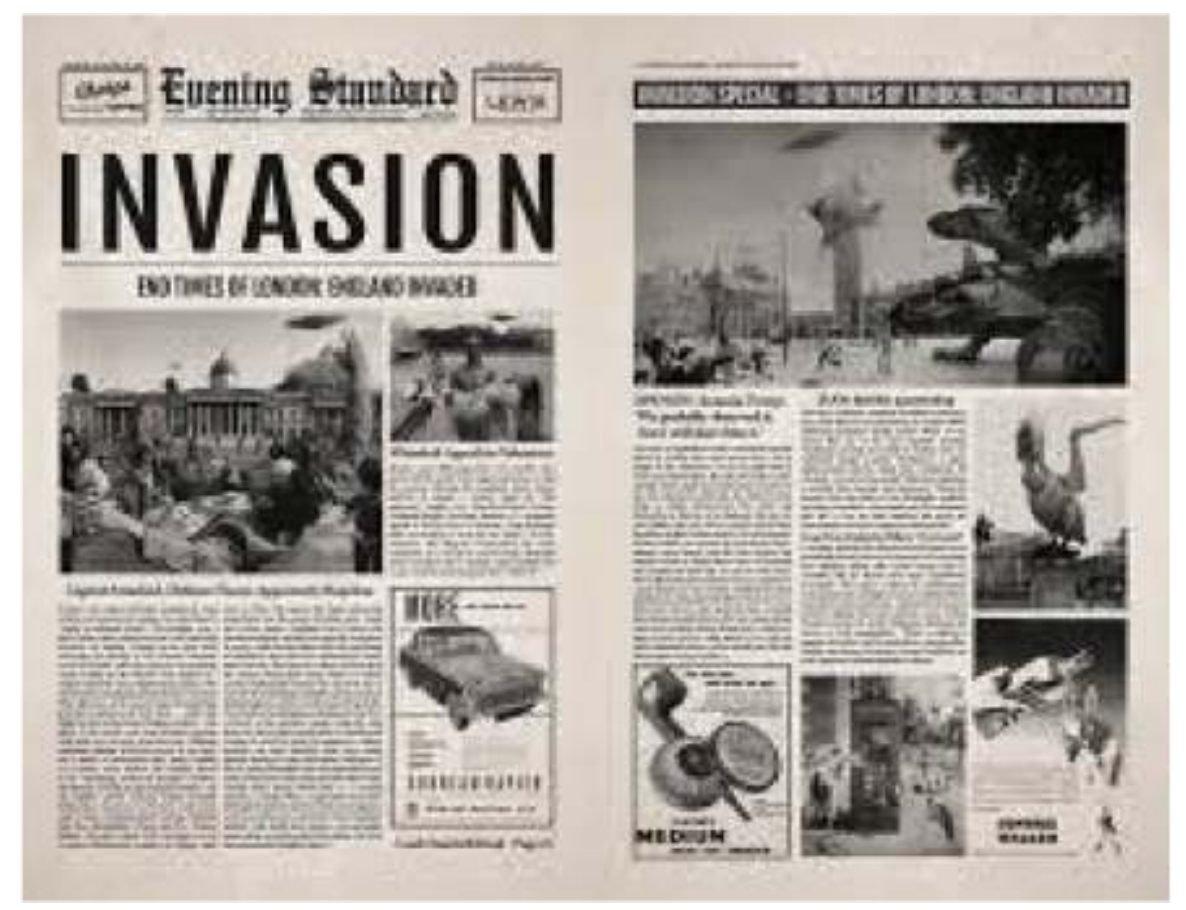

Fig. 6: Cook, Michael, Invasion (Evening Standard), 2017.

Inkjet print (Epson UltraChrome K3 inks on Hahnamuhle Photo Rag Bright White 310 gsm paper). Size $200 \times 135 \mathrm{~cm}$.

13 On another level, photomontages are also a good way to intermingle facts and fiction while offering a reflection on their co-presence and interplay in the piece of art. Cook's pieces always tend to take a historical dimension leading to the telling of other narratives or other histories. For example, one of his series that stands out from the others, when it comes to the choice of models, is Invasion (2018) (See Figs. 5 and 6). All of the people pictured are of European descent and are shown to be trying to escape an alien invasion taking place in central London. The series starts with a double-page spread in the Evening Standard devoted to documenting the events, relying on satire, emphasizing facticity and not facts as readers may expect from a newspaper. Satire and a direct reference to colonial history are evident in the rubric entitled "OPINON" (spelling mistake included), written by some Antonia Twerp, whose evocative name leaves no room for doubt when it comes to the attention and legitimacy that should be given to her piece of writing:

Let's face it: England has a lot to answer for, and the attack on London this week proved that a lot of people in the world have an axe to grind when it comes to ye olde Empire. But jolly ironic jokes aside, and this whole attack is just ripe satire is it not, I'm just not ashamed to admit that the whole invasion thing is simply inconvenient. ${ }^{15}$

14 Cook thus shows that photomontage is another technique to forge narratives and question the greatest narrative of all times-history. In fact, this fake newspaper spread becomes a meta-narrative which provides a kind of background to help understand and contextualize the rest of the pieces that compose the series. The technique also enables the juxtaposition and display of those different narratives, which become different "ways of seeing" to borrow John Berger's words. The use of the medium of the 
newspaper also helps blur the boundaries between facts and fiction, leading Cook's art to become reflexive:

Within these images exists a thicket of meta- and mega-stories, mini-narratives that speak to the past. Historical references tease out racist practices that were imposed on Aboriginals; however, this time, white urban residents of London are the victims. ${ }^{16}$

This blurriness between fiction and reality is also emphasized by the realistic aesthetics of the pictures. Danielle Emmerich underlines this ambivalence in Michael Cook's works, which according to her is one of its most compelling features:

The images are executed to a high standard, almost believably being able to pass as genuine historical documents to someone unaware of the true story of Australia's past, and in this, a type of paradox is created: the technical finesse of the works makes them seem like records of actual events, yet they have a strong dreamlike and surreal atmosphere and in fact, never actually occurred. It is this contradiction of reality and fiction that makes the artwork so significant. [...] More importantly, he has created a duality of fact versus fiction that directly parallels the either/or duality of the European's judgment of the Aborigines to be civilised or savage, based purely on outward appearances. ${ }^{17}$

Indeed, in Invasion, Cook's work once more relies on a role reversal: as opposed to the Undiscovered series (2010) (See Fig. 12), in which the Aboriginal man embodies an explorer wearing European attire setting foot on an unknown land. In this more recent series, Europe-and most specifically London-is invaded by aliens, attacked by UFO's using their lasers to spread terror on British soil. Invasion is all the more striking by its overwhelming saturation of British subjects and Australian fauna. Terror is literally exhaled by each human figure as it is embodied in the silent screams of the crowd: the 'visual loudness' in the faces, movement, and overall, chaos act to silence more than amplify their cries. One may argue that such a work recalls the very silencing of Indigenous voices during colonial invasions. That surprising take on the choice of focus and the resulting creation of a historical fantasy expose history as a discourse written by the colonizers and can act eventually to reclaim the diversity of the narratives it is in fact composed of, working as many re-visions. This trend partakes in the political dimension of Cook's work, whose first series (Through my Eyes, 2010) (See Fig. 3 and Fig. 7) also stood out because of the choice of his models, Australian Prime Ministers. Working from their official portraits, Cook used the morphing method to superimpose the PM pictures and Aboriginal elders' photographs, replacing just their eyes. This body of photomontages perfectly embodies a change in perspective linked to sight, since Aboriginal vision is literally repositioned at the centre of the photographs. The author explains:

The series asks the viewer to rethink the way they view history. We are asked to see these significant Australian faces through someone else's perspective, through Aboriginal eyes.

By overlaying Aboriginal faces, with focus on the eyes, the viewer is asked to consider history with a better understanding of its meaning. ${ }^{18}$

Once more, art offers here another "way of seeing"-literally this time-or of understanding, pointing at a different way of knowing, departing from dominant narratives. 


\section{Layering and Deep Seeing}

As it has already been mentioned, photomontages rely heavily on the technique of layering. However, instead of leading to opacity or occlusion as covering one layer after another might, Cook's layering is what paradoxically allows other meanings and stories to appear: opacity gives way to transparency. This layering can indeed be described as a see-through aesthetics that makes multiple histories and subjectivities appear, resurface and dialogue in the work of art. While the different elements composing the layers can be observed one by one, they nevertheless come to create a unified and coherent whole. For instance, in Through My Eyes (Fig. 7), Michael Cook goes further in creating an ambivalent picture since the audience has difficulty making the difference between the two faces of the Prime Minister and the Indigenous Australian that merge in the image. The morphing technique is only distinguishable because of the blurry contour of the face. It is, however, the superposition of those two elements-that very blurriness-that gives its dialogic meaning to the work. As a matter of fact, layering is necessary for this specific work of art to reach its full significance. Erasing one element, or one layer, would completely change the viewer's perception of the work.

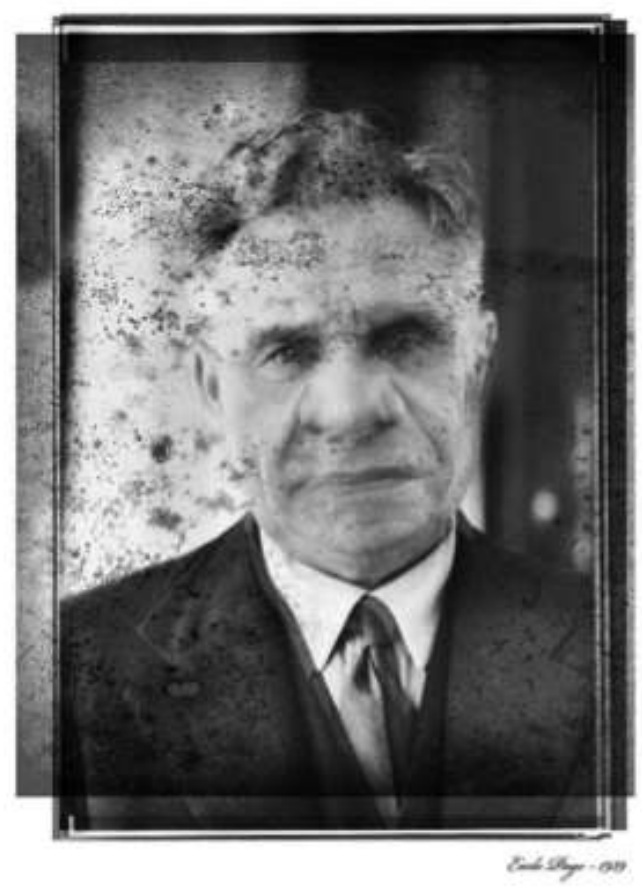

Fig. 7: Cook, Michael, Through my Eyes (Earl Page-1939), 2010.

Inkjet print (Epson UltraChrome K3 inks on Hahnemuhle Photo Rag Bright White $310 \mathrm{gsm}$ paper). Size $50 \mathrm{~cm} \times 40 \mathrm{~cm}$.

Seeing and being seen always interact in Cook's work: layers give depth to the images and use the sense of sight as the main tool to acquire knowledge and to see other stories, which were invisibilized until then. Indeed, since cognition has come to be strongly linked to sight in Western thought, ${ }^{19}$ visual art plays an important role in 
exposing former biased epistemologies and changing them or creating new ones. Santos conveniently reminds his readers that:

Throughout Western modernity a political economy of the senses and sensoriality developed in terms of which hierarchies were established among the senses and among people according to the orientation or acuity of their different senses. The nineteenth century elevated sight and hearing to the top of the hierarchy because they were associated with cognition, while taste, smell, and touch were considered lower senses, particularly developed among the lower races. ${ }^{20}$

In visual art, seeing generates understanding and leads to the recognition of other epistemologies, ways of knowing, subjects and agents. The layering technique also adds some kind of depth to the work of art, allowing "a meeting of seeing and being seen". ${ }^{21}$ This is what Santos calls "deep seeing," and it can be argued that this is exactly what Michael Cook aims at accomplishing in his works, creating "a perspective of deepness built creatively to maximize either proximity or distance, ambiguity or accuracy, movement or stasis." ${ }^{22}$ Santos continues:

Seeing on the terms of the other, where the other is conceived of as an entity that does not depend on the seer, implies requiring that the seer become familiarized with unexpected, often uncomfortable angles and perspectives, and open herself to unpredictable emotions that many put routines and certainties at risk. [...] Deep seeing is performed in different modes. The first concerns the visible and the invisible. In situations of exclusion, resistance, and struggle, the visible is often far less important than the invisible. ${ }^{23}$

21 Cook's art pieces even go further in the process of deep seeing: by pointing at what is invisibilized, such as the baby in the series Mother for example (See Fig. 8), they lead the viewer, or "seer", to question the very process of invisibilization, as it was used on Indigenous populations during colonial times. As far as the series Through My Eyes is concerned, it literally embodies what Santos theorizes as "deep seeing":

Subaltern eyes are bound to be different eyes because they are trained in another culture. [...] A culturally different vision occurs according to perspectives, scales, textures, colors, and movements that may be unintelligible to the postabyssal researcher [...] who studies with and knows with. [...] Knowing-with requires that, in such circumstances, differences be turned into opportunities for intercultural intelligibility. The point is not to eliminate visual cultural differences. ${ }^{24}$

On portraits of officials, Indigenous eyes have been superposed with the original image, literally "Indigen-eye-zing" them, pointing at the need to see reality with different eyes, from another cultural perspective. Only by succeeding in doing so, "intercultural intelligibility" is achieved. Copresence in art becomes a means thanks to which "knowing-with" is possible, and Cook's art may point to the importance of changing scales when it comes to epistemologies, as a way of creating global epistemologies, encompassing Indigenous ways of knowing. Layers are used to expose what was being hidden, or invisibilized, thanks to that play on transparency. Literally and metaphorically, art gains in depth, inasmuch as it acquires other layers of meaning thanks to the elements that are overlapping in the photomontages. As Didi-Huberman notes, the work of the artist is similar to that of an archaeologist, in the sense that they "exhume" what was originally buried, ${ }^{25}$ leading to the conception that the role of the artist reveals and exposes different sets of relations overtime. In Cook's pieces, different temporal layers coexist, creating a kind of temporal diachrony, which cannot be separated from spatial synchrony (that of the work of art): Cook's art strives to 
become all-inclusive. Such depth becomes the primary condition for other subjectivities and histories to emerge, or to be "exposed" in turn.

\section{Rethinking the Artistic Ethics of Space: (G)hosting as Exposing Aboriginal Invisibilization}

Most of Michael Cook's photomontages play on a complex network of presence and absence, to such an extent that they may be considered not only as portraying invisibility, but also as highlighting the politics of invisibilization they intend to disrupt. In the Australian landscape, Aborigines were automatically and wilfully erased during colonization to legitimate the appropriation of their territory: this is embodied in Cook's art by the staging of forsaken figures back in a gloomy and ethereal landscape. Visuality goes hand in hand with questions of authority. Mirzoeff argues, "The authority of coloniality has consistently required visuality to supplement its deployment of force. Visuality sutures authority to power and renders this association 'natural'." ${ }^{26}$ Since visuality was linked to power relations during colonisation, it leads one to the conclusion that as native populations were literally erased from the landscape, they were also erased from the power equation. Hence, it can be said that this play on absence and presence produced and asserted the colonizers' authority, while refusing subjectivity and, even, existence to native populations. This is what Georges Didi-Huberman calls the "under-exposure" and "overexposure" of an object. While those terms are also part of the photographic lexical field, they perfectly emphasize the mechanisms of power that are embedded in the use and production of images, which are to be considered as literal "ways of seeing", rather than images of reality. Didi-Huberman asserts:

Peoples are exposed to disappearance because they are [...] under-exposed in the shade of their censorship or, with a similar result, over-exposed when they are spectacularly displayed. Under-exposure deprives us of the means to see [...]. But over-exposure is not better: too much light is blinding. Peoples exposed to the stereotyped repetition of images are also peoples exposed to disappear. ${ }^{27}$

If in photography over-exposure and underexposure have to be perfectly balanced to produce a good picture, in history, Aboriginal people have tended to be underexposed in relation to their land and overexposed when their culture and sometimes bodies were displayed in Europe as "real specimens" in villages in the World's Fairs or in circuses, for example. 


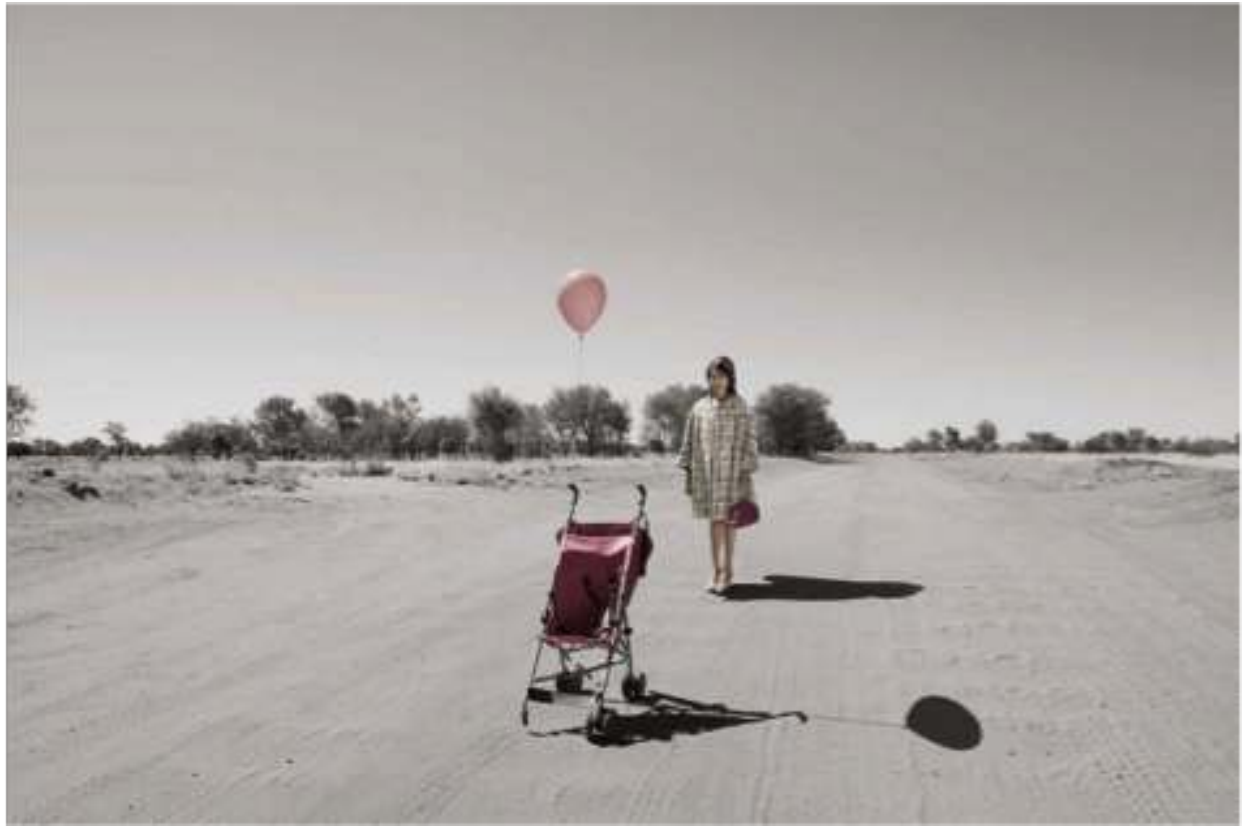

Fig. 8: Cook, Michael, Mother (Pram), 2015.

Inkjet print (Epson UltraChrome K3 inks on Hahnamuhle Photo Rag Bright White 310 gsm paper). Size $180 \times 120 \mathrm{~cm}$.

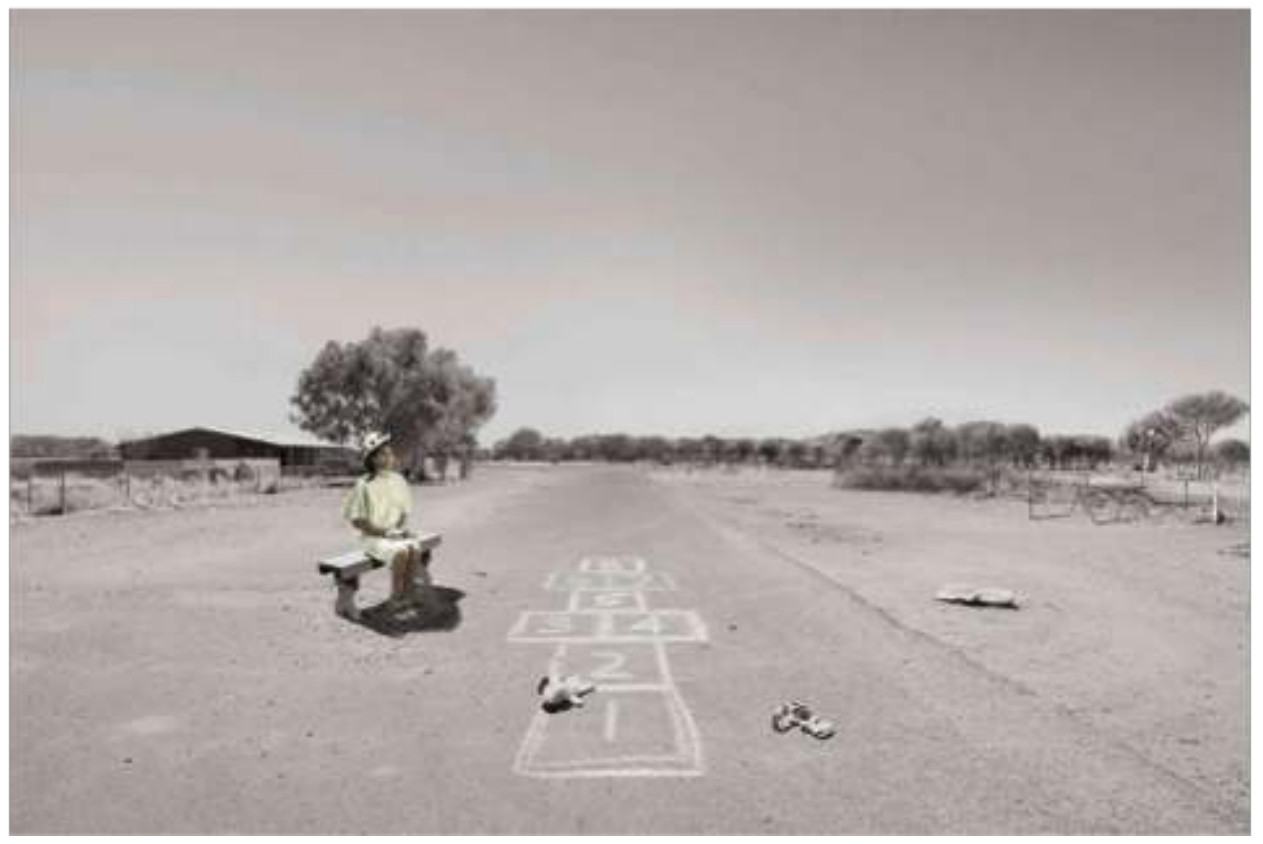

Fig. 9: Cook, Michael, Mother (Hopscotch), 2015.

Inkjet print (Epson UltraChrome K3 inks on Hahnamuhle Photo Rag Bright White 310 gsm paper). Size $180 \times 120 \mathrm{~cm}$

25 The series entitled Mother (2016) (See Fig. 8 and Fig. 9) can be taken as an example to show this staging of the process of invisibilization; the viewer's eye is drawn to a part of the image that reveals an absence, which at first leaves the viewer uncomfortable. The pram as well as the hopscotch are horizontally centred and placed in the lower third of 
the picture, while the mother is slightly decentred, further up in the second third. By attracting the viewer's gaze to the empty centre in the foreground, this unconventional use of the photographic rules of thirds emphasizes these feelings of unease and displacement, since the only living element which also gave its title to the series, the mother, is paradoxically relegated to the periphery of the action, or rather "nonactions" or "non-games". Cook acknowledges this series as being inspired by the Stolen Generations ${ }^{28}$ but such an absence may have gone unnoticed were it not for the objects that are used to frame that very absence: the empty pram, the lonely hopscotch and balloon, as well as the scattered toys. The duration of that absence is emphasized by the different activities that are alluded to, from playing outside to going out for a walk with one's baby in a pram. Quite strikingly the mother as the only subject in the picture is colorized, whereas the background remains black and white. The only other elements that are colorized and therefore made to stand out are the very objects that enhance the absence of the child. While colour leads the eye to linger on the protagonist of the series, it also points painfully at what is missing in the photographs. As a consequence such images do not so much rely on the representation of the landscape, or on the poetics of space, as on the ethics of presence and absence as both are staged in "Country." ${ }^{29}$ In that case, one is also led to consider what could be called the artistic ethics of space, since the question of subjectivity (Which subjects are present in or absent from the work of art?) eventually merges with those of authority (Whose work is it? Who makes such a selection?) and ethics (Why do so? Which power relation is exposed?).

The fact that such an absence is framed by objects may be interpreted as showing how the nonexistence of such populations has been epistemologically produced by colonizers. Boaventura de Sousa Santos explains that initial erasing, or invisibilization of the Indigenous body by what he calls the "epistemologies of the North":

They [the epistemologies of the North] cannot conceive the body as an ur-narrative, a somatic narrative that precedes and sustains the narratives of which the body speaks or writes. The fact that the latter narratives are the only ones that are epistemologically relevant is premised upon the concealment of the somatic narrative that grounds them. The body thus necessarily becomes an absent presence. ${ }^{30}$

27 That way, Cook's work shows such an invisibilization of the indigenous child, while making it an "absent presence", by neatly framing the void it left in the middle of the pictures with meaningful objects pointing at incomplete relations or exchanges with the other subject, the mother. Indeed, the process of invisibilization, embedded in the epistemologies of the North as theorized in Santos's works, is all the more exposed since that emptiness would have gone unnoticed had it not been clearly delineated by objects. This recalls also what Santos explains concerning the production of Western representations of the Other, which he terms the "epistemology of absences":

what does not exist is in fact actively produced as nonexistent [...]. From the point of view of subaltern cosmopolitan reason, reality cannot be reduced to what exists because what exists is only the visible part of reality. [...] Nonexistence is produced whenever a certain entity is disqualified and rendered invisible, unintelligible, or irreversibly discardable. What unites the different logics of the production of nonexistence is that they are all manifestations of the same rational monoculture. ${ }^{31}$

It appears that Michael Cook represents here reality that is actively produced as nonexistent, making it visible in a way, whether it be the original presence of Aboriginal people in Australia, or the stealing of Aboriginal children and its dire consequences on 
generations of Aboriginal Australians. Consequently, such a process of erasure in the work of art mirrors the historical and colonial invisibilization these populations had to endure for centuries.

\section{Repetition as Erasure}

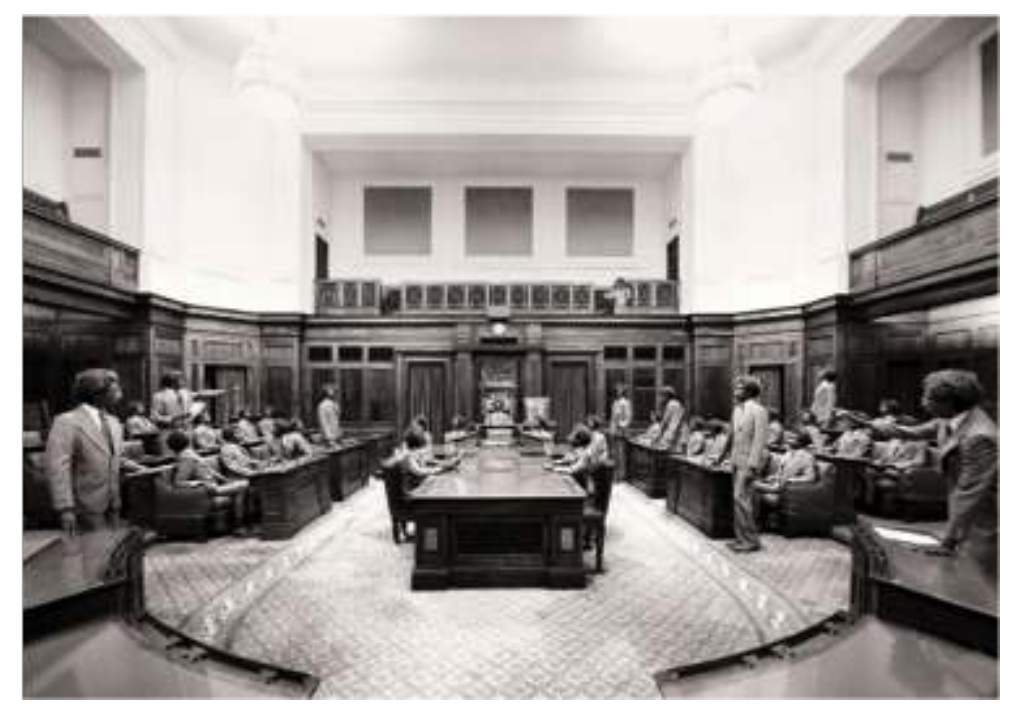

Fig. 10: Cook, Michael, Majority Rule (Senate), 2014.

Inkjet print (Epson UltraChrome K3 inks on Hahnemuhle Photo Rag Bright White 310 gsm paper). Size $200 \times 140 \mathrm{~cm}$.

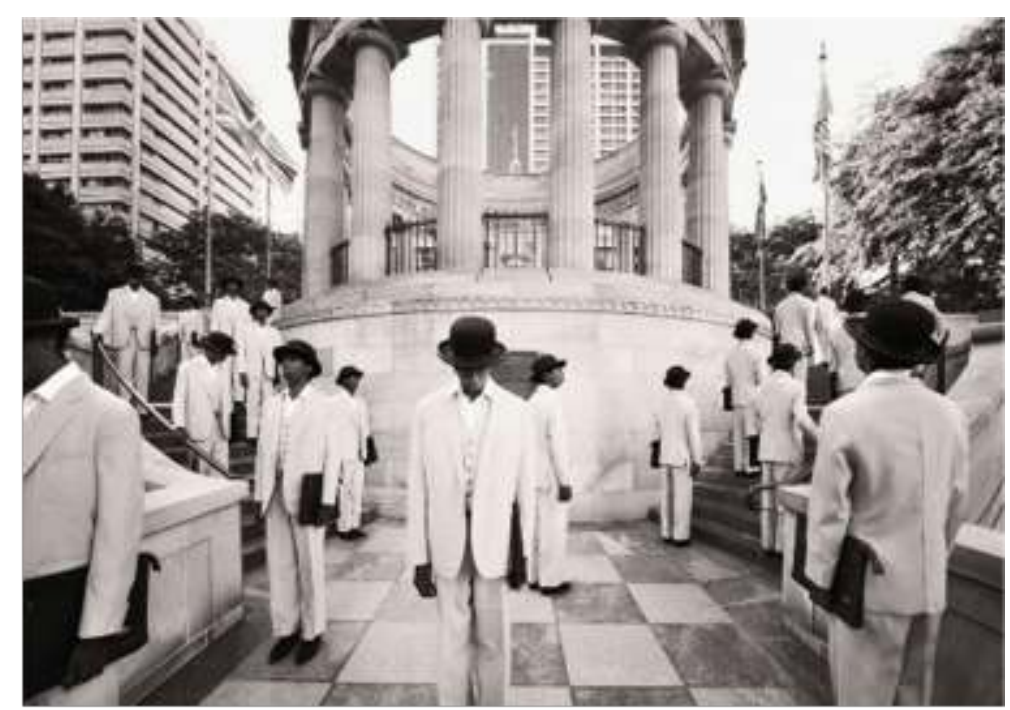

Fig. 11: Cook, Michael, Majority Rule (Memorial), 2014.

Inkjet print (Epson UltraChrome K3 inks on Hahnemuhle Photo Rag Bright White 310 gsm paper). Size $200 \times 140 \mathrm{~cm}$.

Another way that Michael Cook uses photomontage in his works to expose this voluntary invisibilization may seem quite paradoxical at first. In the series entitled Majority Rule (See Fig. 10 and Fig. 11), one single Aboriginal subject is repeated, as if he were copy and pasted, in order to occupy as much space as possible. The artist's point 
of Aborigines taking up the visual and physical space is made clear from the very first sentence on his website where he explains this specific project, "What if Indigenous people were 96 percent of the Australian population and non-Indigenous people defined as the four percent?" ${ }^{2}$ Michael Cook is interested in this reversed situation, but also aims at criticizing, or at least exposing, the fact that Aboriginal Australians are so few compared to Euro-Australians (only $4 \%$ of the Australian population) that they have become nearly invisible, especially in the places that Cook chose carefully: the parliament, a war memorial, a train station, even city streets. However, visual saturation does not seem to make the subjects more visible since the viewer's attention does not focus on just one figure: it is quite the contrary. The viewer is nearly made to discard the Aboriginal man in his individuality, trying to encompass all of his different versions at once and rather considering him as a collective thanks to his repetitive presence in the picture. This notably recalls what Albert Memmi wrote about the different strategies of depersonalizing the colonized:

Another sign of the colonized's depersonalization is what one might call the mark of the plural. The colonized is never characterized in an individual manner; he is entitled only to drown in an anonymous collectivity [...]. [The colonized] does not exist as an individual..$^{33}$

There is indeed the mark of the plural in Majority Rule. The subject is rather perceived as a collective, and not as an individual, being repeated until the figure reaches some kind of exhaustion. Either a real effort has to be made to look at all the figures in their singularity, singling one figure out and looking at him before looking at another one, or one might keep looking at the subject as a collective, maybe looking at one of them but not looking further as they are all the same. This trend also refers to colonial epistemologies: the colonized were just a mass of indistinguishable Black bodies, while Whites were usually individualized and the focus of attention. For example, one commonplace was the single White body of the missionary preaching in the middle of a mass of Black bodies. The individualization of the White body as opposed to the collectivization of Black ones connotes a similar differentiation when it comes to the understanding of culture and civilization by the West. Indeed, according to Tzvetan Todorov in The Morals of History:

'Civilization' is always in the singular [...], and preceded (in French) by the definite article; what is not said, but what is heavily implied, is that our civilization is the civilization, and that there is only one. Not to be like us is to not be civilized, to not be at all. ${ }^{34}$

While Todorov is writing about the relations between France and Bulgaria, here, the same conclusion may be drawn about the colonial contexts of Western nations during the $18^{\text {th }}$ and $19^{\text {th }}$ centuries. While replacing the Black body at the centre of the image, the repetition of the Aboriginal figure in Cook's photographs may also be interpreted as pointing back to this strategy, rendering visible this invisibilization through repetition and collectivization-or rather the denial of individualization. However, this may give rise to another interpretation altogether: since Cook pictures here a reversed majority embodied by the repetition of the Aboriginal character, this could also be interpreted as showcasing the Aboriginal Australians as individualized and as "the civilized" in this scenario as they are given one specific face, that of the Aboriginal man. Hence, the White viewers may feel uncomfortable as well as self-conscious, as they now are the ones to be invisibilized, occupying the role of the minority in Cook's photomontages. 

racial differences and taxonomic trends that grounded racist ideology and "legitimated" racial hierarchies between peoples in the $18^{\text {th }}$ century. The Indigenous people were all part of the category of the "Other", classified as inferior to the White colonizers, who reused the same stereotyped images to depict such populations. Those figures give an illusion of presence, which is in fact reduced to stereotyped representations. In Majority Rules, the Aboriginal man is made invisible in his being denied any individuality, any subjectivity. As a consequence, even though this series aims at hinting at a reversal of power (the ruling of a reversed majority), it seems to be more successful at questioning such a reversal rather than at asserting it. Boaventura de Sousa Santos calls this invisibilization linked to this classification the "monoculture of the naturalization of the differences," 35 leading to "naturalize" the hierarchies structuring social classification. ${ }^{36}$ All differences are here levelled or essentialized as part of the collective, also because of the repetition of the same figure. The individual eventually drowns in the collective.

And yet, in Cook's photomontages, the use of the copy reaches beyond invisibilization and encapsulates in itself the very vector of change and originality, be it in the various postures of the Aboriginal model (Majority Rules) (Fig. 10 and Fig. 11), in the use of marked Victorian aesthetics (Broken Dreams) (Fig. 2), or the use of archival photographic material (Through My Eyes) (Fig. 3 and Fig. 7). In Majority Rules, the viewers' eyes discover as many options as there are representations of the Aboriginal man in the picture, showing another way of reclaiming the photographic space as an Indigenized territory. Indeed, at first, the stark contrast between black and white is also used to emphasize that jarring visual image staging the Aboriginal figure, displaced in an urban westernized environment. However, on second thought (or rather second "gaze"), the viewer's perception unfolds and expands as they come to grasp the different layers of the work which stand out not only as a technical feature but also take on a semiotic and semantic aspect; another meaning emerges and tends to stress the indigenization of the urban setting as a way to point out what could be, a contact zone or a relational space framing a potential reconciliation between elements from different cultures. It may also inform the fact that one needs to go past the dominant pictures of history in order to get to see and become aware of alternatives, such as Indigenous narratives, which intermingle in the photomontage. This can only be done if the viewer focuses on the individual figures, that are mostly placed at the periphery of the picture, for example on both sides of the bus or in the Senate. The representation of the originally invisibilized Aboriginal subject is what eventually allows the primeval void to be filled. Here it can be said that art enables the holes dug by colonial history to be finally filled as a way to patch up and piece back together stories that were silenced. In the end, art operates as presence: the original hosts of the land, the Aborigines, are made to reappear on Australian territory as haunting presences, sometimes even as evanescent ghosts. 


\section{Rehistoricizing Indigenous Subjectivity}

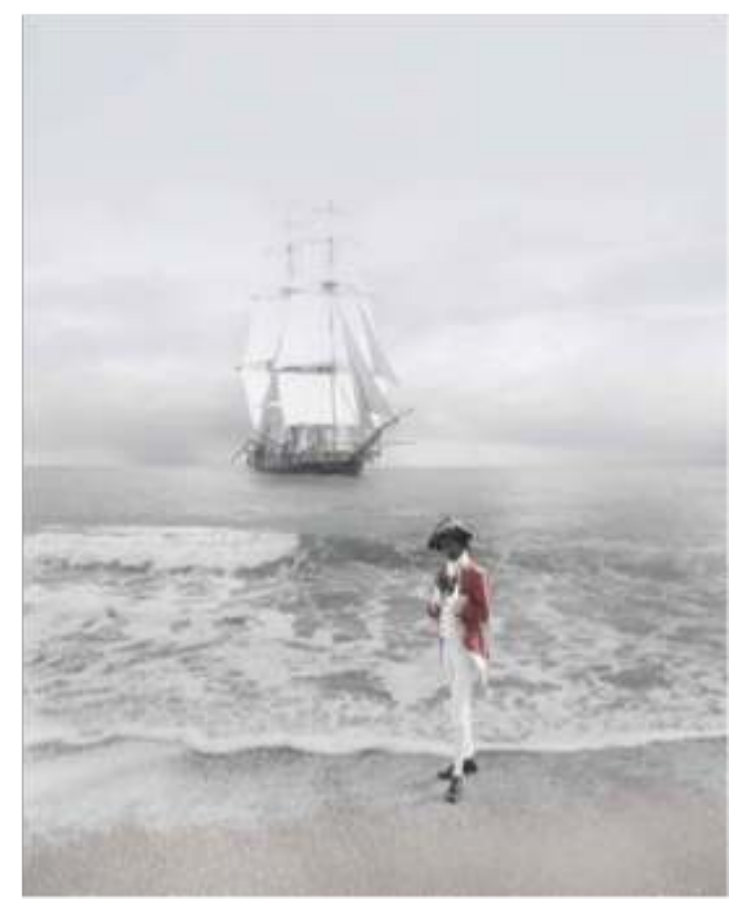

Fig. 12: Cook, Michael, Undiscovered \#4, 2010.

Inkjet print (Epson UltraChrome K3 inks on Hahnemuhle Photo Rag Bright White 310 gsm paper). Size $124 \mathrm{~cm} \times 100 \mathrm{~cm}$.

Most of Michael Cook's series refer to a colonial past set in Australia, such as Undiscovered, Broken Dreams, or The Mission. However, the references to a collective traumatic past, that of the colonial era, in those artistic pieces fulfil a specific role, repositioning Indigenous subjectivity into a collective past while enabling cultural identification to happen in the present. Andrew Lattas explains what is really at stakes in this specific reflexive use of the past:

It is here a question of the need to carry forward a past, not for the sake of carrying forward a dead monument, but in order to reformulate it so as to have some control of the mirror through which one reflects upon one's self and one's community. The past is a set of narratives for reflecting upon one's identity and to this extent it allows people to mirror themselves back to themselves. It is this control of the mirror function of narrative which is part of the politics of identity [...]. ${ }^{37}$

Art takes on a reflexive and self-defining dimension for the native community, relying on a critical inquiry of the past and of history as a Western discursive creation. This helps the community to emerge as agents of their own representations, on a collective, as well as on an individual level, thanks to the artists. The way the past is tackled in these artistic pieces definitely has consequences in the present of these populations. Stuart Hall evokes two different consequences of such practices: first, "a matter of unearthing that which the colonial experience buried and overlaid, bringing to light the hidden continuities it suppressed" and secondly, what could be perceived as "a 'positioning' of the 'figure' of the past in the present, [..]'producing' the past in new ways." ${ }^{38}$ This is typically what happens in Cook's photographs: the Aboriginal community is presented with new ways of representing themselves, their stories, 
thanks to new artistic techniques which also contribute to renewing their cultural representations and finally leading to its contemporary cultural emergence and recognition on an international stage. As a consequence, those works of art play on reflexive and emancipatory drives when it comes to the epistemological systems according to which those communities were first represented: art "mirror[s] [people] back to themselves". ${ }^{39}$ In this way, there is an inherent ontological and political dimension to this art, replacing the Aboriginal subject at the core of the work of art, of the land and of systems of representations. Barbara Bolt explains these consequences by reinscribing the body in the art piece as follows:

[...] there is the potential for a mutual reflection between imaging and reality. In this monstrous performativity, the body becomes language rather than merely inscribed by language. I argue that it is through process or practice that the outside world enters the work and the work casts its effects back into the world. In the dynamic productivity of the performative act, the work of art produces ontological effects. ${ }^{40}$

As mentioned earlier, these ontological effects concern the subject in the pictures, the Aboriginal subject who is repositioned in the land. However, it also operates on the artist, since producing art is what enables him to claim this very status and recover his cultural heritage. Even though Michael Cook was adopted and did not grow up with his community, he explains that creation leads him to reconnect with this part of his cultural identity:

I was brought up with a strong understanding about my Aboriginal ancestry...

When I produce art I feel a stronger connection... This helps me to understand

Australian history-in particular my Australian history. ${ }^{41}$

37 Art is the bridge between individual stories and collective history that finally merge in Cook's photomontages leading his art pieces to take on a specific dimension and go beyond mere representations of the Unreal. Barbara Bolt calls it "the ontology of the work of art"; she concludes on the idea that far from enclosing the work of art in a single interpretation, it conversely leads it to opening up:

The material performativity of [the work of art] suggests the possibility of a materialist ontology of the work of art. The performative power of images and imaging goes beyond its capacity to reveal. ${ }^{42}$

New epistemologies are produced thanks to these pieces of art, which go beyond the seemingly one-dimensional image that is the photograph, opposing the canon and offering new ways of reclaiming visibility, identity and agency, perfectly illustrating Simon During's claim: "identities [...] have to be enacted."

\section{Co-presence as a Call for Reconciliation and Reciprocal Intelligibility}

Cook's art perfectly illustrates this way of rendering present what was first invisibilized: it is not so much about "presenting" as it is about "presenc-ing" what-or rather who-was first produced as nonexistent by colonizers of Australian territory. According to Georges Didi-Huberman, presence can only be co-presence, since the "co-," or the "being with" is inherently contained in any "being," 43 or here in any work of art. For instance, in Cook's photomontages, even though elements from historically conflictual cultures are juxtaposed, the use of such opposition does not merely aim at reversing the original hierarchy based on the relations of power that were established 
during colonization. This co-presence finally underlines the fact that both cultures were affected by colonization, and that the best way to get rid of power relations is to open up the work of art and make it engage in a dialogue between those two cultures. Cook locates this co-presence at the centre of his photographs, which show another world in which it may be possible to live:

The restaging of the past allows the pieces to have a liberating sense of possibility. The world the artist imagines is almost utopian, in that there is no black or white, right or wrong, and questions can be posed without complication of race or equality. The figures depicted are both conquerors and conquered. ${ }^{44}$

40 As a matter of fact, art neutralizes these power-relations; this stands in contrast to Derrida's position that implies a binary always relies on the domination of one of the two over the other ${ }^{45}$ Michael Cook goes against this rendering of a Manichean world, according to Louise Martin-Chew, who reuses the colour metaphor to underline the fact that this juxtaposition of different cultures in his work is what specifically enables him to take a step back from the epistemologies developed in colonial times. Indeed, during the interview that Martin-Chew dedicated to the series Invasion, she evokes "his need to extend himself, to ask questions, and show people the many colours between black and white." ${ }^{46}$ The opposites co-exist and cohabit in art but there are no power relations anymore since one side does not seem to have prevailed. It is their interplay in co-presence that matters, as Santos advocates:

What I propose is [...] to think the terms of the dichotomies regardless of the power articulations and relations that bring them together as a first step in freeing them of such relations and to reveal other alternative relations that have been obscured by hegemonic dichotomies [...]. ${ }^{47}$

41 Only this will enable a dialogue to take place, since a counter-hegemonic stance or discourse does not expect or favour any answer. Two versions of history and two cultures cohabit in Cook's works, without ever calling for a judgement, since the artist prefers to ask questions. As his gallerist, Andrew Baker, says, "You could summarise every body of work Michael has done with the words, 'What if?" 48

While writing about photography and John Berger's theories, Edward Said develops what he thinks are two of the main attributes of photomontages:

[they] use the visual faculty [...] to restore the nonsequential energy of lived historical memory and subjectivity as fundamental components of meaning in representation. Berger calls this an alternative use of photography: using photomontage to tell other stories than the official sequential or ideological ones produced by institutions of power. [...] Second is opening the culture to experiences of the Other which have remained 'outside' (and have been repressed or framed in a context of confrontational hostility) the norms manufactured by 'insiders. ${ }^{49}$

Said then concludes that this process can finally make "that intimate experience intelligible for an audience of modern European readers," or viewers in this case. The superposition of different elements from various cultural backgrounds, such as colonized subjects and European locations (Broken Dreams), Aboriginal subjects wearing European outfits (Broken Dreams, Objects, Undiscovered and Civilized) or even embodying explorers (Undiscovered and Civilized) does not call so much for a recognition of difference but rather for a mutual recognition. Said's idea of "the intelligibility of experience" for a Western audience seems to share the same goals as what Boaventura de Sousa Santos calls "mutual recognition," structuring "the ecology of recognition" 
which comes to be necessary when subjects are denied any agency, as was the case with Indigenous people, for example:

The third logic of the production of absences is the logic of social classification. Although in all logics of production of absence the disqualification of practices goes hand in hand with the disqualification of agents, it is here that the disqualification affects mainly the agents [...]. The sociology of absences confronts coloniality by looking for a new articulation between the principles of equality and difference, thus allowing for the possibility of equal differences - an ecology of differences comprised of mutual recognition. It does so by submitting hierarchy and difference to critical inquiry. It consists of deconstructing both difference (to what extent is difference a product of hierarchy?) and hierarchy (to what extent is hierarchy a product of difference?). [...] The ecology of recognition creates a new exigency of reciprocal intelligibility. ${ }^{50}$

Cook's photomontages endeavour to undertake that necessary critical inquiry, and even operate as a visual critique of former Western epistemologies, or of what Santos termed the "Epistemologies of the North".

\section{Conclusion}

Michael Cook's different collections tell complete narratives from the first piece to the last in the series. When considered together, they display a continuum of representations of relations between former colonized and colonizers. Cook's body of works mostly stage Aboriginal models as they reflect on the consequences of colonization and of history on these populations. Contemporary art, and more specifically here digital photography, is used to enable new epistemologies and, with them, new subjectivities to emerge not only nationally but internationally. It allows Indigenous Australians to be included, or rather reintroduced into, in the national narrative from which they were originally erased and invisibilized by the hegemonic epistemologies of the colonizers.

Decolonizing these epistemologies would consequently involve the emergence of these cultures through reflexivity, which is tightly interwoven with the ideas of emancipation and self-definition: art does not so much show what was first erased from the representations but rather questions the very mechanisms that generated such invisibilization. This very questioning is the first step to the critique of those former epistemologies in Cook's art. Indeed, Asha Varadharajan explains how truth in art may be reached not so much thanks to the elements that are effectively featured, but rather thanks to the dissecting of the "processes" -and maybe intentions? - at work:

[...] if surfaces can't be trusted, neither can depths or buried realities be elicited.

What is crucial is a tracing of the process of displacement itself that produces this conundrum. In short, 'the process of hiding is the structure of truth'. ${ }^{51}$

In a way, Cook's pieces of art become meta-representations, exposing invizibilization rather than rendering visible the Aboriginal subjects that were first invisibilized in the national Australian narrative. It is a way to show alternative epistemologies, by focusing on processes rather than images, since pictures can be easily manipulated to a specific end, as they were by Western epistemologies. What needs to be exposed are those power relations that dominated and dictated the first representations of the native populations, in order to enact a paradigm shift on an epistemological level. By doing so, exposing such mechanisms of domination might lead Western viewers to 
become aware of the biased representations that have always structured their perceptions of the world, leading possibly to a reflexive turn in global epistemologies as well.

\section{BIBLIOGRAPHY}

Bell, Richard. “Aboriginal Art - It's a white thing!,” November 2002. http://www.kooriweb.org/ foley/great/art/bell.html. <accessed on August 10, 2020>

Benterrak, Krim, Stephen Muecke and Paddy Roe. Reading the Country: Introduction to Nomadology. Melbourne: Re.press, 2014.

Bolt, Barbara. Art Beyond Representation: The Performative Power of the Image. London: I. B. Tauris, 2004.

Bowden, Ross. “What is 'authentic' Aboriginal Art?' Pacific Arts , July 2001, No. 23/24 (July 2001), 1-10.

Cerabona Ron. "The Colour of power." Canberra Times, April 29, 2014.

Chandler, Lisa. "Points of View: Michael Cook's Re-imagined Histories." In Photography \& Fictions: Locating Dynamics of Practice, edited by Victoria Garnons-Williams, 20-25. Brisbane: University of Queensland Press, 2014.

Cook, Michael. https://www.michaelcook.net.au/ <accessed on August 10, 2020>

Cook, Michael. Through My Eyes. https://www.michaelcook.net.au/projects/through-my-eyes $<$ accessed on July 14, 2020>

Craig, Gordon and Ryan Presley. Over the fence: Contemporary Indigenous Photography from the Corrigan Collection. Brisbane: University of Queensland Art Museum, 2016.

Derrida, Jacques. Positions. Paris : Éditions de Minuit, 1972.

Didi-Huberman, Georges. Peuples exposés, peuples figurants. Paris : Éditions de Minuit, 2012.

Didi-Huberman, Georges. L'étoilement. Conversation avec Hantaï. Paris : Éditions de Minuit, 1998.

During, Simon. Cultural Studies: A Critical Introduction. London, New York: Routledge, 2005.

Emmerich, Danielle. “Michael Cook's 'What-If' retake on Australia's History." https:// www.eyelinepublishing.com/write-about-art-5/article/michael-cooks-what-if-retake-australiashistory <accessed on September 20, 2018>

Fabian, Johannes. Time and The Other: How Anthropology Makes Its Object. New York: Columbia University Press, 2002.

Foley, Gary. "The Inevitable Collision between Politics and Indigenous Art," 2005. http:// www.kooriweb.org/foley/essays/pdf_essays/ collision\%20between\%20politics\%20and\%20indigenous\%20art.pdf <accessed on August 10, 2020> Hall, Stuart. "Cultural Identity and Diaspora." In Identity: Community, Culture, Difference, edited by Jonathan Rutherford, 222-237. London: Lawrence \& Wishart, 1990. 
Kha, Caroline. "Broken Dreams - Dialogue with Michael Cook.” http://vaaus.co.uk/mcook1/ $<$ accessed on September 20, 2018>

Lattas, Andrew. "Essentialism, Memory and Resistance: Aboriginality and the Politics of Authenticity." Oceania 63-3, (1993): 240-267.

Lorenzo de, Catherine. "Agency and Authorship in Australian Photo Histories." In Photography, History and Difference, edited by Tanya Sheehan, 172-194. Hanover, New Hampshire: Dartmouth College Press, 2015.

Lydon, Jane. "Introduction: the Photographic Encounter." In Calling the Shots, Aboriginal Photographies, edited by Jane Lydon, 1-18. Canberra: Aboriginal Studies Press, 2014.

Martin-Chew, Louise. "Michael Cook talks about staging an Indigenous invasion of London," July 25, 2018. https://artguide.com.au/michael-cook-talks-about-staging-an-indigenous-invasion-oflondon <accessed on September 20, 2018>

Martin-Chew, Louise. “Michael Cook - Exhibition QLD.” Australian Art Review (June 2011): 75.

Memmi, Albert. The Colonizer and the Colonized. Translated by Howard Greenfeld. London: Earthscan Publications Ltd, 2003.

Michael Cook: Invasion [ex. cat.], Andrew Baker Art Dealer, Brisbane, 2018.

Mirzoeff, Nicholas. The Right to Look: A Counterhistory of Visuality. Durham, NC: Duke University Press, 2011.

Nägele, Rainer. “The Scene of the Other: Theodor W. Adorno's Negative Dialectic in the Context of Poststructuralism." Boundary 2 11-2, (1983): 59-80.

Said, Edward. “Opponents, Audiences, Constituencies and Community." Critical Inquiry 9-1, (1982): $1-26$.

Said, Edward. Culture and Imperialism. New York: Vintage Books, 1994.

Santos, Boaventura de Sousa. Epistemologies of the South: Justice against Epistemicide. Boulder, USA: Paradigm Publishers, 2014.

Santos, Boaventura de Sousa. The End of the Cognitive Empire: The Coming of Age of Epistemologies of the South. Durham: Duke University Press, 2018.

Singeot, Laura. "The Museum, from a Colonial Institution to an Alter/native Space: The Construction of the Globalised Subject." The Journal of the European Association for Studies of Australia (JEASA) 11-1, (2020): 15-27.

Todorov, Tzvetan. The Morals of History. Translated by Alyson Waters. Minneapolis: University of Minnesota Press, 1995.

Varadharajan, Asha. Exotic Parodies: Subjectivity in Adorno, Said, and Spivak. Minneapolis: University of Minnesota Press, 1995.

\section{NOTES}

1. To further this idea of Aboriginal art as being tightly linked to Western representations and conceptions of art, as well as how it was commodified by Europeans, see Richard Bell, "Aboriginal Art- It's a white thing!," November 2002. http://www.kooriweb.org/foley/great/art/bell.html $<$ accessed on August 10, 2020> 
2. For more details, see Ross Bowden, “What is 'authentic' Aboriginal Art?' Pacific Arts, July 2001, No. 23/24 (July 2001), 1-10.

3. This categorization has of course been criticized and questioned, notably in the extensive study on Aboriginal art edited by Ian McLean and strikingly entitled How Aborigines Invented the Idea of Contemporary Art (2011).

4. Catherine de Lorenzo, "Agency and Authorship in Australian Photo Histories," in Photography, History and Difference, ed. Tanya Sheehan (Hanover, New Hampshire: Dartmouth College Press, 2015), 172.

5. Gordon Craig and Ryan Presley, Over the Fence: Contemporary Indigenous Photography from the Corrigan Collection (Brisbane: University of Queensland Art Museum, 2016). These political and cultural considerations are more complex than they seem since another epistemological issue appeared in the 1990s: many Indigenous artists strove to be recognized as "contemporary" artists, and refused to be categorized as "Indigenous," according to what they considered an essentializing trend reducing them to their cultural background. Aboriginal activist Gary Foley claimed at that time, "Australian indigenous art should be exhibited in the modern art galleries of Europe rather than the ethnographic centers where at that time it languished." For more details on Australian art as modern art, see Gary Foley, "The Inevitable Collision between Politics and Indigenous Art," 2005, 2. http://www.kooriweb.org/foley/essays/pdf_essays/ collision\%20between\%20politics\%20and\%20indigenous\%20art.pdf <accessed on August 10, 2020>

6. Jane Lydon, ed., Calling the Shots, Aboriginal Photographies (Canberra: Aboriginal Studies Press, 2014), 6 .

7. For more details on the study of Cook's photography and its historical and ethnographic inspirations, see Laura Singeot, "The Museum, from a Colonial Institution to an Alter/native Space: the Construction of the Globalised Subject," JEASA 11-1, (2020): 15-27.

8. Krim Benterrak, Stephen Muecke and Paddy Roe, Reading the Country: Introduction to Nomadology (Melbourne: Re.press, 2014), 171.

9. Santos, Boaventura de Sousa, Epistemologies of the South: Justice Against Epistemicide (Boulder, US: Paradigm Publishers, 2014), 59-60.

10. Santos, Epistemologies of the South, 60 .

11. Between 1768 and 1779, Captain James Cook undertook three voyages around the world during which he notably stopped in the South Pacific, more specifically on the Australian coasts, where he completed and corrected the pre-existing maps. He was killed in Hawaii possibly after a misunderstanding with Indigenous people. However, his logbooks are still one of the most read and studied accounts of those voyages of exploration and the objects he brought back with him to Europe formed the first extensive collection of Pacific artifacts of the British Museum.

12. Caroline Kha, "Broken Dreams - Dialogue with Michael Cook." http://vaaus.co.uk/mcook1/ $<$ accessed on September 20, 2018>

13. Lisa Chandler, "Points of View: Michael Cook's Re-imagined Histories," in Photography \& Fictions: Locating Dynamics of Practice, ed. Victoria Garnons-Williams (Brisbane: University of Queensland Press, 2014), 20-25.

14. Edward W. Said, Culture and Imperialism (New York: Vintage Books, 1994), 3.

15. Michael Cook: Invasion [ex. cat.], Andrew Baker Art Dealer (Brisbane 2018), 11. Other attacks are humorously described, “[...] the city can't simply stop every time a colonial outpost turns the tables on their former masters. We all remember the day London was attacked by giant Bengal tigers, animate onion bhagis, and the river became one massive stream of mango lhassi. [...] There is a good chance we may soon be visited by Canadian grizzly bears [...]."

16. Michael Cook: Invasion [ex. cat.], 14.

17. Danielle Emmerich, "Michael Cook's 'What-If' retake on Australia's History." https:// www.eyelinepublishing.com/write-about-art-5/article/michael-cooks-what-if-retake-australiashistory <accessed on September 20, 2018> 
18. Michael Cook, Through My Eyes. https://www.michaelcook.net.au/projects/through-my-eyes $<$ accessed on July 14, 2020>

19. See the theory of "visualism" or the "rhetoric of vision" developed by Johannes Fabian in Time and the Other. Johannes Fabian, Time and the Other: How Anthropology Makes Its Object (New York: Columbia University Press, 2002).

20. Santos, Boaventura de Sousa, The End of the Cognitive Empire (Durham: Duke University Press, 2018), 166-167.

21. Santos, End of Cognitive Empire, 171.

22. Santos, End of Cognitive Empire, 171.

23. Santos, End of Cognitive Empire, 172.

24. Santos, End of Cognitive Empire, 175.

25. Georges Didi-Huberman, L'étoilement. Conversation avec Hantaï (Paris: Minuit, 1998), 86-87.

26. Mirzoeff, Nicholas, The Right to Look: A Counterhistory of Visuality (Durham: Duke University Press, 2011), 9.

27. My translation from the original, which reads, "Les peuples sont exposés à disparaittre parce qu'ils sont [...] sous-exposés dans l'ombre de leurs mises sous censure ou, c'est selon, mais pour un résultat équivalent, sur-exposés dans la lumière de leurs mises en spectacle. La sous-exposition nous prive des moyens pour voir [...]. Mais la sur-exposition ne vaut guère mieux: trop de lumière aveugle. Les peuples exposés au ressassement stéréotypé des images sont, eux aussi, des peuples exposés à disparaître." Georges Didi-Huberman, Peuples exposés, peoples figurants (Paris: Éditions de Minuit, 2012), 15.

28. The "Stolen Generations" is a term that refers to the Australian Aboriginal and Torres Strait Islander children who were forcibly removed ("stolen") from their families and placed in white Australian households to receive an "education," which, more often than not, resulted in them becoming domestic servants. This practice was authorized as early as the 1870 s by the Victorian Aboriginal Protection Act. Children were still being taken from their families in the 1970s. Prime Minister Kevin Rudd issued an official apology in February 2008, which was adopted as a motion by both the House of Representatives and the Senate. Michael Cook acknowledges this historical inspiration in an interview conducted by Louise Martin-Chew. See Louise Martin-Chew, "Michael Cook talks about staging an Indigenous invasion of London," July 25, 2018. https:// artguide.com.au/michael-cook-talks-about-staging-an-indigenous-invasion-of-london <accessed on September 20, 2018>

29. This is the term used by Aboriginal Australians and Torres Strait Islanders to refer to Australian landscape in a broader sense including a strong feeling of belonging as well as spiritual links to the land and all things inhabiting it.

30. Santos, End of Cognitive Empire, 88.

31. Santos, Epistemologies of the South, 171-172.

32. Michael Cook, https://www.michaelcook.net.au/projects/majority-rule, <accessed on August $12,2020>$.

33. Albert Memmi, The Colonizer and the Colonized, trans. Howard Greenfeld (London: Earthscan Publications Ltd, 2003), 129.

34. Tzvetan Todorov, The Morals of History, trans. Alyson Waters (Minneapolis: University of Minnesota Press, 1995), 6.

35. Santos, Epistemologies of the South, 173.

36. Santos writes: "its consists of distributing populations according to categories that naturalize hierarchies." See Santos, Epistemologies of the South, 173.

37. Andrew Lattas, "Essentialism, Memory and Resistance: Aboriginality and the Politics of Authenticity," Oceania 63-3, (1993): 255.

38. Stuart Hall, "Cultural Identity and Diaspora," in Identity: Community, Culture, Difference, ed. Jonathan Rutherford (London: Lawrence \& Wishart, 1990), 222-237. 
39. Andrew Lattas, "Essentialism, Memory and Resistance: Aboriginality and the Politics of Authenticity," Oceania 63-3, (1993): 255.

40. Barbara Bolt, Art Beyond Representation: The Performative Power of the Image (London: I. B. Tauris, 2004), 10.

41. Louise Martin-Chew, "Michael Cook - Exhibition QLD," Australian Art Review, June 2011, 75.

42. Louise Martin-Chew, "Michael Cook - Exhibition QLD," 75.

43. Didi-Huberman, Peuples exposés, 104.

44. Emmerich, "Michael Cook's 'What-If' retake on Australia's History."

45. Jacques Derrida, Positions (Paris: Éditions de Minuit, 1972), 56-57.

46. Louise Martin-Chew, "Michael Cook talks about staging an Indigenous invasion of London."

47. Santos, Epistemologies of the South, 171.

48. Ron Cerabona, "The Colour of Power," Canberra Times, April 29, 2014, 6.

49. Edward Said, "Opponents, Audiences, Constituencies and Community," Critical Inquiry 9-1, (1982): 25.

50. Santos, Epistemologies of the South, 177-8.

51. Rainer Nägele, "The Scene of the Other: Theodor W. Adorno's Negative Dialectic in the Context of Postructuralism," Boundary 2 11-2, (1983): 75.

\section{ABSTRACTS}

This article aims at demonstrating Aboriginal photographer Michael Cook's ability to address the Aboriginal subjects of his photomontages in their very absence, as a paradoxical way to counter the primeval colonial drive which erased the traditional custodians of the Australian land. As a consequence, focusing on the photomontage and layering techniques, I will demonstrate how Cook exposes and debunks former colonial epistemologies while making two different visions of the world coexist. Far from being synonymous with occlusion and opacity, layering paradoxically becomes the privileged means of unveiling and discovering the recurrent invisibilization processes that systematically targeted Indigenous Australians in History. As a consequence, it is not so much about an expansion than a reconfiguration of the visual field that is targeted by Cook in his art. Finally, I will endeavour to show that by rehistoricizing invisibilization, Cook's photography eventually advocates reconciliation, while repositioning an aestheticized Indigenous subject at the centre of his work.

\section{INDEX}

Keywords: Michael Cook, Aboriginal contemporary art, terra nullius, photomontage, layering

\section{AUTHOR}

\section{LAURA SINGEOT}

Laura Singeot's interest as a researcher lies in the representations of indigeneity in contemporary Indigenous literatures in Australia and New Zealand. She examines the rewritings 
of colonial history and epistemologies in contemporary Pacific fiction, while scrutinizing the subversion of Western literary codes. She has also published on museology and the visual arts of the Pacific, especially new digital art such as Michael Cook's photomontages. Her next submissions explore poetry, eco-criticism and the inclusion of contemporary Indigenous art pieces in urban environments.

Université Paris Nanterre - CREA 